Omar Ahmed Muhammad Abdul Aal El-Nemr

\title{
Patterns of Manipulation in Philip Roth's The Plot Against America
}

\section{Omar Ahmed Muhammad Abdul Aal El-Nemr}

Demonstrator - English Department - Faculty of Education - Ain Shams

Abstract:

University

This paper attempts to demonstrate how Philip Roth in The Plot Against America utilizes the manipulative function of Moral Duty to further the development of the plot, both as a literary term, and as a conspiracy. It becomes evident that Roth, by tracing the philosophical roots of the concept of moral duty, does not only concur with how this concept is defined, as shown in his portrayal of his characters, but he also develops this concept. He does that in such a way that enables him to present the plot, in both of its senses, as a moral time loop, which ends as it begins. Thus, this paper follows a moral approach towards his novel, The Plot Against America, in order to discern the different patterns of duty-driven manipulation, which set the plot into a nonlinear track of narration that is phased through an older narrator, recounting the memories of his younger self in an alternative historical timeline.

Keywords: Philip Roth, Manipulation, Moral Duty, Moral Approach, Plot, Conspiracy, Jewish American Literature, Alternative History, Holocaust

$$
\begin{aligned}
& \text { تسعى تللك الدراسة إلى توضيح الكيفية التي يتبعها فيليب روث في استخدام مفهوم الواجب }
\end{aligned}
$$

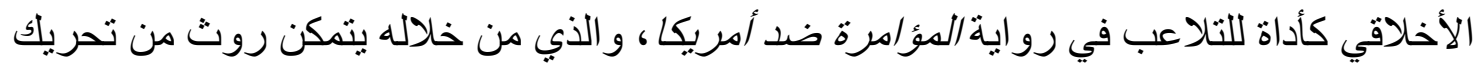

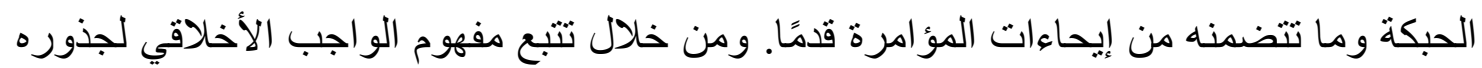

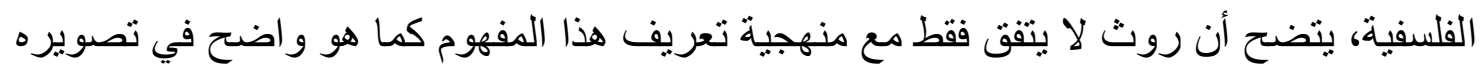

$$
\begin{aligned}
& \text { لثخصياته الروائية، بل يطور هذا المفهوم بطريقة ما تمكنه من تقديم الحبكة الروائية لتلك الرواية } \\
& \text { وكذللك فكرة المؤامرة المصاحبة لها كحلقة زمنية مفر غة محملة بالدلالات الأخلاقية وتتتهي حيثما } \\
& \text { تبدأ. ومن ثم، نتناول هذه الدراسة الرواية من منظور أخلاقي حتى تبين أنماط التناعب المدفوع }
\end{aligned}
$$

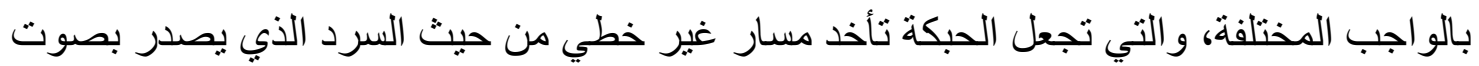

$$
\begin{aligned}
& \text { راوي أكبر سنًا يروي ذكريات طفولته في خط زمني لأحداث تاريخية بديلة. }
\end{aligned}
$$


Philip Roth, in The Plot Against America (2004), wittingly employs the different denotations of the term plot to demonstrate how this plot, in both its literary and non-literary meanings, is only moving forward by the power of moral manipulation that is enacted through the moral duty of the characters. This is initially suggested by deliberateness of choosing the word "plot" as the keyword for the title of his novel, for it does not only create the much-debated idea of how a narrative plot, commonly acknowledged as a sequence of events that further the development of a work of fiction, would convey the plot - the conspiracy-that is supposedly against America, but it also raises the question of why it is such a controversial issue to determine the conspirators, if there is indeed a plot. An answer to such questions can be found in how Roth, a writer who believes that "being born a Jew is morally demanding," implies the manipulativeness of moral duty, as initially reflected in the first meaning the word "plot" would signify, which is that of a 'conspiracy' (Reading Myself and Others 14). Such an initial thought can be traced in how a conspiracy "consists not merely in the agreement of two or more but in their intention" (Harno 630). Through such an intent, the manipulativeness of moral duty is revealed.

Although Roth acknowledges through his fiction that the conception of moral duty is both reason-driven and law governed, as traced in the writing of such philosopher as Cicero and Kant, he develops such a conception into a tool of manipulation that moves the plot, with both of its denotations, forward. Nevertheless, this conception has its roots back to the classical era, where Cicero, in his treatise De Officiis (On Duties), bases his understanding of duty mainly on reason, believing that it can only be established through reason, which "lifts us above the brute" (111). The same conception of moral duty as being reason-driven similarly echoes in Kant's "categorical imperative," which can be defined as, "an objective, rationally necessary and unconditional principle that ... must [be] always follow[ed] despite any natural desires or inclinations ... to the contrary" (Johnson and Cureton). In light of this principle, Kant, in his Groundwork of the Metaphysic of Morals, introduces what he calls "good will" and maintains that to enact good will in one's actions, good will must be associated with moral duty, which becomes good will in action by providing the agent with the supreme moral motivation, which is how Roth utilizes it (10).

Part of how Roth develops the concept of moral duty is traced in how he also concurs with the entailed precedence of moral duty towards the greater good - an idea that Cicero gives voice to in his treatise. He states: "promises are ... not to be kept, if the keeping of them is to prove 


\section{Omar Ahmed Muhammad Abdul Aal El-Nemr}

harmful to those to whom you have made them; and, if the fulfilment of a promise should do more harm to you than good to him to whom you have made it, it is no violation of moral duty to give the greater good precedence over the lesser good" $(7,35)$. In this regard, he goes so far as to show his willingness to dismiss emotion-driven moral attributes, such as promise-keeping in favor of a more reason-driven moral duty, pursuing the greater good. He thus passes what can be deemed as a moral law dictating that "reason commands, appetite obeys" (103). This law connotes a certain willingness of the agent to perform certain deeds that may go against his/her own desires. Additionally, in light of such a law, Kant holds that the agent must uphold his/her moral duty, not because of being emotionally inclined to do so, but because he/she is law-bound to perform the given duty, putting aside his/her desires, if the fulfillment of his/her duty deems it so. He thus describes duty as "the necessity of an action done out of respect for the law," as it is unhindered and undisturbed by any other motives or inclinations (16).

In the way he depicts his characters, Roth, in principle, concurs with how moral duty, as a law-governed, reason-driven motivation-providing factor functions. He presents his characters in a morally dualistic way, and does not only do so on the interactive level between characters-so that one character would find moral opposition in another-but he also takes such dualism on the level of the single character itself. In enacting moral dualism as a method of exposing the manipulativeness of moral duty, Roth uses such moral duty to camouflage some of them, as to hide them in plain sight at one stage of the plot, and to be at the center of the plot at another. Nathan Marx and Sheldon Grossbart, the characters of Roth's short story "Defender of the Faith," testify to such manipulativeness, which may be the reason for earning him the infamous notion of, in rabbi Theodore Lewis's words, "depict[ing] the Jewish characters in his short stories and novels as depraved and lecherous creatures" (Issac 84).

The character of Nathan Marx "did not seem to bother anybody," as Roth states, for it "did not strike them at all," demonstrating how he camouflages such a character with its sense of moral duty (Reading Myself and Others 60). Roth craftily maintains such a character with whatever moral obligation entailed by being morally "dutiful, almost to the point of obsession," rendering it seemingly invisible to the critical and ever defaming eyes of the critics, who always accuse him of being "self-hating" and "anti-Semitic," and who would efface his fiction in the wake of a raging tempest of "moral categorizing" $(57,60)$.

When Marx commits the supposed sin of "betray[ing] the trust" of Grossbart, the character after which Roth coins the term "Grossbartism," his betrayal does not warrant any critical responses similar to the ones that 
Grossbart receives (60). Nathan Marx, as a Jewish character, and his moral duty-driven morality, which can be similarly referred to as Marxism, thus earn amnesty from such moral offences as being "unlikely, incredible [and] 'made up" (60). In this manner, Roth's morally dualistic depictions of his character reflect how the manipulativeness of moral duty can even extend to the readers themselves, for they would overlook Marx's sin, excusing what can be argued to be an immoral act in essence, in light of how the character of Marx gives precedence towards the greater good to fulfill what he believes to be his moral duty. They, on the other hand, are manipulated to condemn Grossbart, who is a character, in Roth's words, "whose lapses of integrity" are believed to be "actually committed in the name of integrity," in light of how his lapsed sense of moral duty would obstruct that of Marx (60).

Roth phases the manipulative function of moral duty through his plot, which reflects such spatial-temporal unity that does not only take shape in his protagonist's "sixth sense," that he refers to as the "geographic sense, the sharp sense of where he lived and who and what surrounded him", but also exists in the time-lapse narration of an older narrator, who situates the events of the novel in a middle stage, between a past and an untold future (Plot 212). In such a stage, the noveldeliberately - neither offers a conclusion, nor does it continue the events of a forgotten past. This may have motivated some critics to view its ending as abrupt, like how Sanford Pinsker states that "the novel's last paragraphs simply dribble off the page, without making it clear if the Jewish worries [Roth] chronicles are evidence of paranoia or justifiable" (63). Such abruptness, however, is what allows Roth, who has his narrator place the events in an alternative timeline, present these events as a fraction in time that ends as it starts, in a state of perpetuity. Roth thus divides the plot into three phases, with each phase leading into the following through the utilization of moral duty, without which, there would be a standstill. This is especially evident in how the main event of the novel, namely Lindbergh's ascendence to the presidency, is something that is out of the characters' hands, and renders their actions nothing but reactions.

The first phase lies within the confines of a past whose hold over the present does not wane but persists. Such is implied in how Roth has young Philip, despite his childish youth, give a vivid account of such a past, where the modest family that only aspired for "little more" is robbed of its supposed happiness (Plot 1). Such happiness, traced in young Philip's words of "we were happy family in 1940," establishes the link between the temporal and spatial elements of the plot, which Roth utilizes 


\section{Omar Ahmed Muhammad Abdul Aal El-Nemr}

to gradually develop the manipulativeness of moral duty (2). This is achieved by how Roth has his narrator, an older Philip Roth, mingle the events of the past with his younger self's present, as manifested in the repeating state of reminiscence, which signify how such a past remains manipulative through whatever sense of moral duty it bodes. The purpose of the older narrator, whom Roth uses to phase the narration of the supposed plot, is to demonstrate how some Jews, embodied in the Roths, are manipulated by their sense of moral duty. Thus, it is implied that the main purpose of the vivid accounts given through this narrator, contrary to the remark of Mark Shechner that "the stubborn, principled heart of this book is Herman Roth," is not one character, but a certain pattern of moral motivation that shapes the (re)actions of the characters (15). In addition, the very first word written, which is "fear," to which voice is given by the older Philip describing his childhood "memories" over which "perpetual fear ... presides," indicates that the phasing of the narration through an older Philip even proves that his childhood was a moral time loop, whose past, present, and future is manipulated by such a pattern of moral duty (Plot 1).

A shift from such a happy past towards a fearful present is first noticed in how Roth, through young Philip, simply gives a description in a way that does not do harm to the innocence of a child, nor does it ruin the experience with coarse moral attitudes, as Roth himself states that he "tried to keep both the boy's perspective and the adult's perspective from overwhelming the events ("The Story Behind"). He establishes a greater moral duty towards a community that the Jews of America consider a hard-earned utopia, which they will dutifully defend against any attempt to penetrate it or drag it into the troubles of a world that would hinder their moral duty to such a community. Thus, Roth robs the Jewish families of their supposed happiness by the potential threat Lindbergh poses to their hard-earned community, where "work," and the moral duty it entails towards one's family is more sacred than "religion" (Plot 3). However, Lindbergh is not truly introduced as a threat, but an illusion of a threat. Such is traced in how Roth in "The Story Behind 'The Plot Against America" acknowledges that Lindbergh, as a character, "doesn't do that in my book either," referring to the persecution of the Jews. Roth even adds saying that Lindbergh does "very little." His only purpose, as Roth implies, is to expose "what American Jews," among of whom the Roths, "suspect, rightly or wrongly" ("The Story Behind"). He does so in light of how they are manipulated by their moral duty to instantly declare the "great hero," or as such they have heralded him once, a "villain," whose mere name "has provoked" a great degree of "indignation" in every Jewish house in the Jewish utopia (Plot 5, 6). 
Such indignation towards a present reality finds its duty-driven motivation in the past, for the inexplicable loyalty to FDR Herman, Philip's father, maintains by bringing up the topic regardless of the context testifies to this state of clinging to the past, which the older Philip later describes as the "uncommon ... ailment called why-can't-it-be-the-way-itwas" (172). Herman is so stuck in the past, embodied in FDR, that he continues to relate any achievement to FDR, by asking their tour guide, "under FDR?" and expressing his disapproval of the present, as in Lindbergh, by stating "look what we got instead" (62). This clinging to a manipulative, duty-providing past does not stop at Herman, for it is naturally passed unto young Philp, for he, a young child, is morally molded into an image that only ensures the preservation of their utopian society. Such is indicated when Philip states how he "learned to hate" Lindbergh, just like how he "was taught to love" Roosevelt (7). By letting "the boy be a boy while at the same time introducing through the adult's voice a mediating intelligence," Roth demonstrates how young Philip only hates or loves out of his dutiful moral allegiance to a warrior of a father and a saint of a mother, or as such he perceives them ("The Story Behind").

Therefore, the hatred or love young Philip is taught, the decision of Herman, the "manly provider" of his family, to abandon his dream of becoming an "American homeowner" that is given through an opportunity of a promotion are all acts that are done out of the preservation of their utopian community (Plot 8). Duty-bound, Herman is more than willing to go as far as sacrificing his job-which he later does-and refuse the promotion, which prompts his wife's guilt-ridden question of "can the company fire you for turning them down?" (12). This, in a way, agrees with what Alex Hobbs states regarding the character of Herman, saying that his "masculinity is not fixed in stereo-typed gender roles but is responsive to his family's needs" (121). Yet, such a notion does not necessitate that he is not rigidly driven by his moral duty, which might be the reason behind the flexibility of his masculinity. Thus, his morally resolute answer of "I did what I did" testifies to his unfaltering moral duty to his community, for whose greater good he does not hesitate to abandon the very "axiom," of always embracing the alternative, even if it was out of reach; the axion he had "schooled" his sons in (Plot 11,12). Thus, young Philip is left no choice but to be morally indoctrinated out of his filial moral duty into adopting what the older narrator describes as his father's misguided "bitter hatred" and his mother's "ingrained mistrust" (14). 


\section{Omar Ahmed Muhammad Abdul Aal El-Nemr}

In light of such moral duty, one could not help but wonder how the majority of American Jews would react if things were hypothetically reversed. Would they so zealously participate in a conflict not their own for the sake of a minority, or would they issue a mandate, similar to Lindbergh's "mandate to keep America out of the European war" (16). In the current situation of Lindbergh's isolationism, the Jewish families literally evict themselves out of their homes out of "terror" for the safety of their small community (10). They only see Lindbergh's "mandate" as an act of betrayal against the Jews of Europe, yet they fail to see that it is also an act born of loyalty towards the American people; an act that they would probably not hesitate a second in doing out of their dutiful loyalty to their community. In this regard, Lindbergh, when he states, "we cannot allow the natural passions and prejudices of other peoples to lead out country to destruction," is not othering the Jews of America into nonAmericans; he is simply describing a reality that is already there. The majority of American Jews are already acting the punishment of selfothering without even committing the crime of 'plotting against America' (13).

However, the way that the older Philip chooses to liken the Jews' reception of such news to a "real roaring forge" that is fueled by "anger" to become a "furnace that takes you and twists you like steel," is indicative of the manipulativeness of moral duty (16). It is what truly manipulates and twists all the Jewish families in young Philip's neighborhood into how they were "driven from their homes" out of "terror," enacting the punishment of self-eviction out of their own houses, supposedly for no other reason but to vent their "anger." The older Philip writes that such anger is "what shocked a child most" (10). He realizes that they were angry not as Jews on whom "the United States had declared war," as Elaine B. Safer states (150). Instead, they are furious that - in the wake of Lindbergh's isolationism - they are morally expected to suddenly act as Jews in light of a moral duty they sought to bury and replace with the duty to a work-driven community, whose "safety" stands threatened by the "menace posed" by Lindbergh's "affront" (Plot 16, 18). Their anger, he realizes, is only a smokescreen for their fear of the supposed harm that they are supposed to face, for they are "abruptly thrust into the miserable struggle from which they had believed their families extricated by the providential migration of the generation before" (17).

To the eyes of young Philip, they are "plain people who happened to be Jews," yet as the older Philip writes these events, he realizes that they are plain Jews who happened to be Americans, and they do not even realize that themselves, for they unconsciously remain morally stuck in the struggle of their forebearers (17). Despite claiming that they have not 
"retained no allegiance, sentimental or otherwise, to these Old World countries," as conveyed by young Philip, they do retain an allegiance that goes beyond such counties to include the moral heritage they have carried on their shoulders to America (17). They are thus forced to see anything not in their favor, or so they believe, as a "trick ... to shut [them] up and to catch [them] off guard," as proclaimed by the angry Jewish families (17). They fail to merely consider the truthfulness behind Lindbergh's words, and are manipulated by their moral duty to rigidly interpret "Lindbergh and war" as Lindbergh is war against the Jews of America (30).

Such representation of Jewish characters is perhaps what earns Roth the crime of creating a "distorted image of the basic values of Orthodox Judaism," as Rabbi Emanuel Rackman accuses him of (Reading Myself and Others 57). This is perhaps why the Jewish philosopher, Gershom Scholem, is driven to spew venom at Roth, calling him "the lowest of the self-hating low," for he seemingly "revels in obscenity" (Prochnik 457). It is not obscenity that Roth presents, as much as he demonstrates how his characters' moral duty manipulates them into such bizarre acts that warrant the disapproval of the likes of Scholem. Such acts may include how an American family de-americanizes itself, at the wake of Lindbergh's low-flying, which the older Philip describes as being forced to stand there like patriots and watch with the rest of them" (Plot 75; emphasis added). They are simply the ones who are othering themselves. This incarnates their belief that they are the 'America' against which a 'plot' is being conceived.

Nevertheless, the real plot is the one that the Jews conceive against each other. Such is traced in the way through which Roth chooses to depict the children in his novel, as such characters best embody the function of moral duty. He has young Philip conduct a comparison out of his moral duty, where he compares himself to his brother, Sandy. On one hand, young Philip, manipulated by his filial moral duty, consciously denies himself of his best hobby of stamp collecting, believing that he would no longer be able to hunt for stamps under Lindbergh's rule, simply because "[he] was a Jew," as he proclaims (22). He expresses his unconscious inheritance of his parents' fear in how he wishes for "Aladdin's lamp" to conjure him the stamps that his Jewishness supposedly deprives him from collecting (23). Such is a fact that the older Phillip confesses in how he identifies himself the "good child, obedient both at home and at school" (24). He realizes how the young version of himself has shown promise to be morally manipulated into adopting the same moral attitudes of his parents and to demonstrate moral willingness to inherit the moral legacy of the past. 


\section{Omar Ahmed Muhammad Abdul Aal El-Nemr}

Sandy, on the other hand, shows enough moral resistance to the moral indoctrination of his family, when they try to use his hobby against him, instilling in him the fear that he will not be able to practice his drawing during his time in the Just Folks program. However, the drawings that Sandy sends regularly with his letters testify to how he refuses to be morally molded in light of their indoctrination, and is consequently manipulated by his moral duty, not towards his family, but towards Lindbergh, his aunt and Rabbi Bengelsdorf. This is traced in how young Philip later expounds such a comparison, by showing how his brother opposes his parents' moral vilification of Lindbergh as a "frightening villain or a menace to mankind" (25). Instead, he would only see him as a "virile hero," resisting their duty-driven indoctrination (25).

In order to resist their sense of moral duty, Roth has Sandy develop his own sense of moral duty, which he proclaims by stating: "[Lindbergh] is going to president," which he follows by "America's going to go fascist" (25). Sandy, who is often described as being "truthful," not "secretive" or "deceptive" shows his true moral nature out of his moral duty Lindbergh. He would even try to morally manipulate young Philip into becoming morally loyal to Lindbergh by twisting his arm into being as secretive and deceptive as him. He threatens him with the stamp he has of Lindbergh, Philip's "single most valuable possession," warning him that it would meet the fate of his Lindbergh's portraits, if young Philip fails to "keep [his] little trap shut" (27). Like his parents, Sandy goes as far as to exploit his brother's fear, by manipulating him into accepting the duty of not speaking of his Lindbergh's drawings, as if they were his own. He thus accepts to let Sandy hide them under the "bed beside [his]," being unable to even "dare to raise them as an issue" (27). Through such manipulation of Philip's fear, Sandy, the "brother whose reassurance [he]'d never needed more" is rendered "unapproachable" (37).

A similar reaction to young Philip's reaction towards his brother is traced in the moral attitude of the Roths towards rabbi Bengelsdorf. The moral duty of the Roths renders them distrusting of one of their own, especially in light of Bengelsdorf's pledge of unyielding loyalty he makes to Lindbergh on behalf of the American Jews "to crush all doubt of the unadulterated loyalty of the American Jews to the United States of America," as he states (35). Such a pledge is consequently dismissed intolerantly as betrayal. A similar judgement is passed by Elaine B. Safer, who describes Bengelsdorf as a "pompous social climber who tries to sell the Jewish citizenry the anti-Semitic plan to leave their community" (7). Such a judgement is indeed traced in the Roths are manipulated into showing such duty-driven intolerance towards Bengelsdorf, justified by how 'un-Jewish' his speech, as it is likely condemned to be, is. 
To further demonstrate the manipulativeness of moral duty, Roth creates a rift between the supposedly unified moral duty of Herman and Alvin, Philip's cousin. While both Alvin and Philip's father seemingly sympathize with the fate of Europe's Jewry, Herman would seek to deny Alvin his decision of joining the Canadian army fight Hitler's Germany. Such a decision exposes how each is manipulated by his own sense of moral duty, as Alvin chooses a course that opposes the one Philip's father tries to force upon him. This moral course is embodied in the character of Steinheim, whom Philip's father regards as being a "genius," while Alvin considers the same person as a "fake," and a "swindler." (Plot 40, 45, 47). This inevitably leads to one of the defining conflicts of the plot, in both its senses. When Philip's father tells Alvin "you're wrong. Dead wrong," only to face Alvin's "You're wrong!" as an echo, it is revealed that the former is governed by the moral duty of embracing the greater good, even if it means contradicting one's morality, while the latter is moved by his moral duty towards the fate the Jews of Europe are facing (51). Infuriated by such moral duty, Alvin intolerantly declares war "against the Jews" whom he describes as being a "disgrace to the Jews" (52).

A similar war is declared, when a conflict of the same nature, ensues between Herman and Sandy, in which the latter breaks free of his filial moral duty through a series of acts of defiance. The most notable of these acts is the secret conversation he has with his younger brother, where Roth has Sandy demonstrate how he is so intoxicated by the idea of moral duty that he becomes morally willing to accept the extreme alternative as long as it means defying his father. Thus, he tells Philip that he has eaten pork and is planning to "keep eating it now" (98). In this regard, Roth presents Sandy as a live arena in which both his parents and Aunt Evelyn and Bengelsdorf struggle for moral dominion, each hoping to morally manipulate him through their own sense of moral duty.

Such is evident in Evelyn's "bringing" of Bengelsdorf to Herman's doorstep as a clear attempt to morally dethrone Herman, whose patriarchal throne is to be filled by Lindbergh (100). Roth would create such an event to intensify the moral challenge posed by her through Bengelsdorf's presence. Despite the fact that Herman willingly forfeits his throne to Lindbergh's pawn — or so he deems him to be - as the older Philip writes about how he remembers he "was instructed beforehand not to ... go anywhere near [his] father's armchair, which was for the rabbi to occupy before [they] ate dinner," he inevitably voices a rather late response in the face of the repeated moral challenges the rabbi poses by proclaiming Sandy as a moral model for "Jewish adults" $(102,107)$. However, he fails to morally manipulate Sandy back to his filial moral duty, as Sandy's 


\section{Omar Ahmed Muhammad Abdul Aal El-Nemr}

moral resentment towards his father is so intensified that he "turned to [Philip] and made a face that revealed how far he'd spun out of the family orbit" (109).

In addition, young Philip is not morally unaffected, for the rabbi's vilification of Alvin's dutiful sacrifice provides him with enough reason to adhere his mere presence, for no other than the idea that "he has only one leg!" manipulating a badge of honor into a badge of shame (109). Such adherence, as Roth intends, does not only expose the manipulativeness of moral duty, but represents the dualistic technique of characterization. Such is traced in how young Philip finds himself forced to embrace a moral fact that he has every reason to adhere. This leaves him in a moral blender where he struggles to maintain his moral duty both to his father, as he keeps trying "not to stop believing" in him, and to his brother, whom he endeavors to "remember to conceal [his] secrets" (126). In a similar sense, young Philip finds it his "job to run to Alvin next" to embrace him as a war hero, even when he struggles hard to endure the foul stench reeking of his mouth and body. Roth has young Philip decide to remain morally dutiful to his father "by being the best little boy imaginable, much, much better than Sandy and better even than" his true self, despite his adherence towards the presence of Alvin, manifested in his only concern with the stump (133). Roth does so to demonstrate what it means to be bound by one's moral duty, as traced in how young Philip obliges himself with attending to Alvin's needs, earning him the title of being Alvin's "good boy" whose head he pets "like a dog's" (137). He does so out of his moral duty, hoping that his efforts may pass as an "improvised prayer imploring the household gods to protect [their] humble fiver rooms ... from the vengeful fury of the missing leg" (133).

Evidently, the older Philip directly states how his younger self is self-manipulated by his moral duty into ending up as a "boy who worshipped" Alvin (144). Such is traced in how Alvin rewards young Philip for his fealty with a medal of honor. However, the way young Philip would obscure the medal and later dispose of it gives voice to Roth's manipulativeness. It also gives voice to the kind of fear that dominates this inward moral conflict; the fear to fail one moral duty only to fulfill another. Roth symbolizes this fear in how young Philip feared the cellar because of the "dead," of whom he "had little or no recollection" (140). His fear is not of the ghosts of the dead, who are forever "judging and condemning," as much as it is the fear of failing to inherit their moral legacy (140). This is traced in his moral helplessness embodied in the apology of "I am sorry for whatever I did that was wrong," and thus his sudden moral shift towards the stump is explained, by embracing the fate of becoming the "personal valet to a decorated Canadian war hero," who 
excels in "bandaging his stump" in light of how he "practiced enough on" himself $(140,142,145)$.

Even as a child, young Philip finally begins to understand that it is his moral duty towards Alvin that drives him to stand by him. He denies himself his own desire to change his room - a fact that he would "have loved" - out of the greater good of preventing any moral conflicts between Sandy, "who now works for Lindbergh" (133). In such a situation, young Philip realizes how he acts out of his moral duty, even if he inwardly despises this fact, and at such an event in the plot, it becomes clear that he would be stuck in a moral fate that is "endless," or perpetual (137). This is traced when he defends Alvin against his Uncle Monty, as he directly states: "some things you don't know why you do them ... You just do them, Uncle Monty. You can't not" (151). The way Roth has the older Philip retain such words also testify to how he now understands that he was driven by moral duty. Young Philip is so morally loyal to Alvin at this point of events that he adopts a stance similar to that of his parents regarding their community; an extreme stance in which he is more than willing to literally sew his uncle's mouth shut, using the "long still needle and heavy thread ... to shut [his] uncle's mouth," in dutiful defense of Alvin (152).

The manipulativeness of such moral duty thus explains the subsequent change of heart young Philip demonstrates towards Alvin and Herman, the former is condemned, and the latter is redeemed in his eyes. His sense of moral duty now compels him back to the moral path where he "cursed [Alvin] on behalf of his father" (162). He justifies this by how Herman's moral duty endures, whereas Alvin's duty, embodied in his rebelliousness, is so broken that he "could [not] stop himself from abandoning the desire to ever again be anyone's hero," as young Philip remarks (162).

This back-and-forth change of young Philip's sense of moral duty is not only characteristic of the manipulative function of moral duty that Roth utilizes in his fiction, but it also gives voice to young Philip's greatest fear. Such fear is being morally haunted by the dead, not only for failing to fulfill his moral duty to the living, but also for failing the duty, where the living must atone for the dead, by shouldering the moral legacy his father resolutely carries. He enacts this by his inexplicable fear in how he was senselessly quick to conclude that it was "my father" who "had committed suicide". The consequent result is that young Philip "wails," but the tears he sheds are not only for the supposedly dead father, but they are also for himself, for he would spend a lifetime being haunted by the moral duty he has failed to fulfill to his father (169). 


\section{Omar Ahmed Muhammad Abdul Aal El-Nemr}

The moral irony that young Philip realizes through his father and Alvin is how the pursuit of their moral duty only ends with failing such a moral duty. In realizing that this might be his moral fate, if he abides by his moral filial duty, young Philip resorts to direct his sense of moral duty towards himself. Such is repetitively traced in the many instances where he desires to escape or to "go to the corner and get on a bus and disappear" (190; emphasis added). His moral duty to himself makes him want to "find Alvin," even after all the intolerance he harbors against him, so that he would "never live with [his] family again" (190). His moral duty to his father thus diminishes, giving way to the perpetuity that Roth suggests at the beginning of the novel, which is traced in his understandable desire to morally renounce his sense of moral duty, because it dispels his "peacetime illusion of an eternal, unhaunted now" (225).

His desire gains even more solidity, in light of how his moral duty to his "devoted father" who is "no more capable of protecting his family from harm than was Mr. Wishnow hanging dead in the closet," deteriorates especially with the ever-increasing moral tension between Sandy and his father (226). Such negates the view that this later desire of young Philip to "divorce himself from history, from being a Jew" is born of Lindbergh's "anti-Semitic treatment" (Safer 158). In this regard, the plan he eventually plots to escape his moral duty is not a reflection of "Philip's sense of guilt over his wish to become an orphan," nor is it a manifestation of "his mental and physical breakdown," as Yael Maurer states (58). Such a plan of wanting "only to disappear" and to "wake up ... somewhere else" becomes more than that, as it represents him moral entrapment in a perpetual cycle of moral duty (220). It takes on the shape of a moral decision that is neither "impulsive," "hysterical," "reckless," nor guilt-ridden, but one that is purely born of own sense of moral duty towards himself, as he no longer can "hear another panic-stricken word from anyone" (228, 232; emphasis added).

This leaves him as someone who is not young Philip, rather an "orphan" (233). However, he is not driven by "the fear of being orphaned," as Timothy Parrish argues (140). Instead, he is filled with such "determination to resist a disaster [his] family ... could no longer elude and might not survive," that he no longer becomes "terrified" 232 of the ghosts in the basement of his house, because they no longer have a reason to condemn and judge him, as he is no longer the 'Philip Roth' burdened by the moral duty of his family (232). Such determination to escape his family to their moral fate brings about his determination to only take his "stamp album" out of his fear that "it was intolerable to think" that his album would be "given away wholly ... to another boy" (233). Roth adds 
this minor detail that older Philip retains to implicitly point towards the clinging to the past young Philip demonstrates. This album is thus more than just a collection of stamps. It is rather the embodiment of a perpetual duty-providing past that is too valuable to be lost.

The idea of perpetuity, however, is not only reflected in how young Philip's personal plot fails, but it is incarnate in how life gets back to the way it was with such "wonderous fairy-tale swiftness" (239). This proves how Roth is not concerned with detailing "the appearance of a fascist and anti-Semitic movement in the United States in the early 1940s," as much as he is concerned with exposing the manipulativeness of moral duty, which endures, even when the events of the plot take place in an imaginary historical timeline, which Roth ends at the snap of a finger (Safer 152).

To further stress such manipulativeness, Roth, in such an alternative historical reality, does not only let the older Phillip banish the state of Israel from existence to eliminate whatever sense of moral drive that the presence of the Jewish state would drive and manipulate the Jews out of which, but he also goes as far as to eliminate the supposedly original cause for and purpose of the establishment of Israel; that is the Holocaust. Such a notion is partially reflected in Michael Rothberg's argument that, in his words, "it is less the Holocaust and its impact on American life that obsesses Roth than the unbridgeable distance" not "between the Holocaust and American life," as Rothberg would demonstrate, but between the Holocaust and the Jews of today, who Roth, through his fiction, proves that most of their attempts to bridge this gap, or "to lessen that distance," merely end in becoming stuck into a vicious circle of moral duty (Parrish 53).

Roth even reduces the establishment of Israel into a cause for pity. Roth, by "transforming the tragic into the banal," as Alan Cooper describes, demonstrates through the plot(s) that some Jews would quickly find alternatives to the Holocaust to justify their moral rigid sense of moral duty (Royal 242). In proclaiming that "Israel didn't yet exist," and that "six million Jews hadn't yet ceased to exist," Roth demonstrates through the perpetuity of potential plots how the Jews did not only find the "establishment of a national Jewish national Homeland in Palestine" a necessity that would instill them with moral duty (Plot 4). Additionally, he demonstrates how the Jews, through their alternative hard-earned utopian community, within which they-out of their moral duty-reduced the totality of America, inevitably condemn themselves to a historicallyrepeated fate at the hands of another Hitler ("Brief and Incomplete History"). 


\section{Omar Ahmed Muhammad Abdul Aal El-Nemr}

It thus can be concluded that Roth does not only utilize the concept of moral duty as a motivation-providing factor that drives his Jewish characters into a certain course of action, but he also develops this concept in such a way as to demonstrate how the narration of his plot, in its both senses, only moves forwards through such a concept. In doing so, Roth creates a state of moral perpetuity, where one sense of moral duty leads to the next. And such perpetuity is traced in the different patterns of moral manipulation he creates through the use of moral duty. 


\section{Works Cited}

Cicero, Marcus Tullius, and Walter Miller. De Officiis. Harvard University Press, 1997.

Harno, Albert J. "Intent in Criminal Conspiracy." University of Pennsylvania Law Review and American Law Register, vol. 89, no. 5, 1941, pp. 624-647.

Hobbs, Alex. "Family and the Renegotiation of Masculine Identity in Philip Roth's 'The Plot Against America." Journal of American Studies, vol. 46, no. 1, 2012, pp. 121-137. JSTOR, www.jstor.org/stable/41427315. Accessed 1 Feb. 2021.

Isaac, Dan. "In Defense of Philip Roth." Chicago Review, vol. 17, no. 2/3, 1964, pp. 84-96.

Johnson, Robert and Cureton, Adam, "Kant's Moral Philosophy", The Stanford Encyclopedia of Philosophy (Spring 2019 Edition), Edward N. Zalta (ed.), $<$ https://plato.stanford.edu/archives/spr2019/entries/kant-moral/>.

Kant, Immanuel, Allen W. Wood, and J B. Schneewind. Groundwork for the Metaphysics of Morals. New Haven: Yale University Press, 2002.

Maurer, Yael. “'If I Didn't See It with My Own Eyes, I'd Think I Was Having a Hallucination': Re-Imagining Jewish History in Philip Roth's The Plot Against America." Philip Roth Studies, vol. 7, no. 1, 2011, pp. 51-63. JSTOR, www.jstor.org/stable/10.5703/philrothstud.7.1.51. Accessed 1 Feb. 2021.

Parrish, Timothy. The Cambridge Companion to Philip Roth. Cambridge University Press, 2007.

Pinsker, Sanford. "Scary Scenarios, Personal and Otherwise." Hadassah Magazine October 2004: 63.

Prochnik, George. Stranger in a Strange Land: Searching for Gershom Scholem and Jerusalem. Granta Books, 2018.

Roth, Philip. The Plot against America. New York Vintage Internat, 2004.

--. "Defender of the Faith." The New Yorker, 14 Mar. 1959.

--. Reading Myself and Others. Vintage Books, 2007.

--. "The Story Behind 'The Plot Against America'." The New York Times, The New York Times, 19 Sept. 2004, www.nytimes.com/2004/09/19/books/review/thestory-behind-the-plot-against-america.html.

Royal, Derek. Philip Roth: New Perspectives on an American Author. Praeger Publishers, 2005.

Safer, Elaine B. Mocking the Age: The Later Novels of Philip Roth. State University Of New York Press, 2006.

Shechner, Mark. "Roth's Fanfare for the Common Man.” Forward 1 Oct. 2004: 11, 15.

"A Brief and Incomplete History of Jewish Suffering: Chosen People." Chosen People Ministries, 3 Mar. 2020, www.chosenpeople.com/site/a-brief-andincomplete-history-of-jewish-suffering/. 